\title{
Absence of oxytocin-neurophysin messenger RNA in the Day-18 bovine conceptus*
}

\author{
Renata A. C. Van Vliet, J. S. Walton, A. G. Wildeman $\dagger$, K. J. Betteridge $\ddagger$ \\ and Ann M. Verrinder Gibbins
}

Department of Animal and Poultry Science, $\dagger$ Department of Molecular Biology and Genetics, and $\ddagger$ Department of Biomedical Sciences, University of Guelph, Guelph, Ontario, Canada NIG 2WI

\begin{abstract}
Summary. Total cellular RNA was isolated from conceptus tissue obtained from 22 superovulated cows 18 days after artificial insemination. Total RNA was also isolated from luteal tissue from 3 cyclic cows 7 and 8 days after oestrus. Luteal and conceptus RNA were simultaneously subjected to formaldehyde-agarose gel electrophoresis and transferred to nitrocellulose by bidirectional diffusion blotting. Northern blots were probed using cDNAs specific for bovine oxytocin and bovine $\beta$-actin gene sequences. Hybridization of the oxytocin cDNA to RNA was consistently observed on autoradiographs as a 0.6 kilobase $(\mathrm{kb})$ band in lanes containing corpus luteum RNA, but was not detected in lanes containing conceptus RNA. The presence of conceptus RNA on the blots was confirmed by hybridization of the actin cDNA to conceptus RNA, which resulted in a $2 \cdot 0 \mathrm{~kb}$ band on autoradiographs. These results suggest that oxytocin is not synthesized by the bovine conceptus on Day 18 of gestation.
\end{abstract}

Keywords: oxytocin; conceptus; messenger RNA; $\beta$-actin; cattle

\section{Introduction}

Luteal maintenance is critical to the establishment of pregnancy in the cow. The first signal for luteal maintenance occurs between Days 17 and 19 of gestation (Northey \& French, 1980) and results in an attenuation of the release of prostaglandin (PG) F-2 $\alpha$ (Thatcher et al., 1984), the agent responsible for regression of the corpus luteum (CL) in the cyclic cow (Kindahl et al., 1976).

Production of PGF- $2 \alpha$ by the non-pregnant uterus is stimulated by oxytocin. For example, administration of oxytocin in vivo has been shown to result in the release of PGF-2 $\alpha$ (Lafrance \& Goff, 1985) and immunization of ewes against oxytocin delays luteal regression (Sheldrick et al., 1980). Although oxytocin concentrations in bovine plasma are highest in the mid-luteal phase (Schams et al., 1985), the sensitivity of the uterus to oxytocin, as determined by the release of the PGF-2 $\alpha$ metabolite 15-keto-13,14-dihydro-PGF-2 $\alpha$ ((PGFM) into the circulation, appears to be highest from Day 17 to oestrus (Lafrance \& Goff, 1985), a period that correlates with peak oxytocin receptor concentrations during the oestrous cycle (Meyer et al., 1988). Uterine sensitivity to oxytocin therefore appears to be more a function of oxytocin receptor concentration than of circulating concentrations of oxytocin (Soloff \& Fields, 1989).

In the pregnant ewe, oxytocin receptor concentrations decrease during the time of luteal maintenance, in contrast to increasing oxytocin receptor concentrations in the cyclic animal (Sheldrick \& Flint, 1985). Continuous infusion of oxytocin into the uterus of cyclic ewes (Flint \& Sheldrick, 1985) and cows (Gilbert et al., 1989) prolongs the oestrous cycle, and in the ewe results in decreased oxytocin receptor concentrations (Flint \& Sheldrick, 1985) and a decrease in PGF-2 $\alpha$ concentrations (Sheldrick \& Flint, 1987).

* Reprint requests to J. S. Walton. 
One potential strategy, therefore, that could be adopted by the developing conceptus to prevent luteolysis would be the continuous synthesis of oxytocin in close apposition to the endometrium, which could facilitate down-regulation of oxytocin receptors (Flint et al., 1989). Small amounts of oxytocin have been detected in ovine conceptuses between Days 14 and 29 of gestation (Lacroix et al., 1988), but this does not necessarily indicate conceptus synthesis. In an attempt to determine more definitely whether oxytocin is synthesized by the bovine conceptus we searched for messenger RNA (mRNA) specific for oxytocin-neurophysin in the conceptus during the period of maternal recognition of pregnancy.

\section{Materials and Methods}

Animals. Twenty-two cross-bred beef cows at an average age of 4.5 years (range 3-6 years) were divided randomly in groups of 3 or 5 for oestrous cycle synchronization and superovulation, using 1750 i.u. pregnant mares' serum gonadotrophin (PMSG) (Equinex: Ayerst Laboratories, Montreal, Quebec, Canada), as described by Walton \& Stubbings (1986). Cows were artificially inseminated 36,48 and $60 \mathrm{~h}$ after the last cloprostenol (Estrumate: Cooper's Agropharm, Inc., Ajax, Ontario, Canada) injection. At 18 days after insemination cows were slaughtered by stunning with a captive bolt pistol followed by exsanguination, and reproductive organs were removed immediately.

The oestrous cycles of 3 beef cows were synchronized with 2 injections of cloprostenol (each $500 \mu \mathrm{g}) 11 \mathrm{days}$ apart to allow for collection of corpora lutea. Cows were slaughtered on Days 7 or 8 of the following oestrous cycle and the ovaries removed immediately.

Isolation of RNA. Conceptuses were flushed immediately into Petri dishes with phosphate-buffered saline (PBS, $\mathrm{pH} 7.4$ ), on four separate occasions (Preparations 1 to 4). Corpora lutea, obtained by rapid dissection from ovarian tissue, were chopped into $1-2-\mathrm{mm}$ pieces with a scalpel blade on ice.

Total cellular RNA was isolated immediately from these tissues using the guanidinium/hot phenol method and precautions to prevent degradation of RNA described by Maniatis et al. (1982) with the following modifications. Precipitation of RNA was carried out by adding $0 \cdot 1$ volume $3 \mathrm{M}$-sodium acetate and 2 volumes absolute ethanol and allowing the mixture to stand overnight at $-20^{\circ} \mathrm{C}$. After recovery of the RNA by centrifugation the pellet was washed with $70 \%$ ethanol, dried in a vacuum desiccator, and dissolved in diethylpyrocarbonate (DEPC)-treated water.

The concentration of the solution was determined spectrophotometrically assuming that an absorbance of $1 \cdot 0$ measured at $260 \mathrm{~nm}$ in a $1-\mathrm{cm}$ light path is given by a solution containing $45 \mu \mathrm{g} \mathrm{RNA} / \mathrm{ml}$. The solution was divided into samples of $200 \mu \mathrm{g}$ RNA and sodium acetate and ethanol added as described above. The samples of RNA were stored in ethanol at $-70^{\circ} \mathrm{C}$.

Electrophoresis and transfer of $R N A$. Samples of total luteal and conceptus RNA ( $40 \mu \mathrm{g}$ each) and two sets of RNA molecular size standards (Bethesda Research Laboratories, Burlington, Ontario, Canada) were subjected to electrophoresis in $1.5 \%$ agarose gels containing $2.2 \mathrm{M}$-formaldehyde (diluted from $12.3 \mathrm{M}, 37 \%$ solution in water; Caledon Laboratories, Georgetown, Ontario, Canada) and $1 \times$ running buffer $(40 \mathrm{~mm}$-morpholinopropanesulphonic acid, $10 \mathrm{~mm}$-sodium acetate, $1 \mathrm{~mm}$-EDTA) for $4.5 \mathrm{~h}$ at $60 \mathrm{~V}$ with buffer recirculation. In preparation for electrophoresis RNA samples were dissolved in $3.6 \mu \mathrm{l}$ DEPC-treated water and $2 \mu \mathrm{l}$ each of the RNA molecular size standards dissolved in $1.6 \mu \mathrm{l}$ DEPC-treated water. To each RNA sample and RNA molecular size standard were added $1.6 \mu \mathrm{l} 5 \times$ running buffer, $2.8 \mu \mathrm{l} 12.3 \mathrm{M}$-formaldehyde and $8 \mu \mathrm{l}$ deionized formamide (Fisher Scientific, Unionville, Ontario, Canada). The formamide previously had been deionized by mixing with mixed bed ion-exchange resin (AG 501-X8d, 20-50 mesh; Bio-Rad Laboratories Ltd, Mississauga, Ontario, Canada). Samples were incubated at $55^{\circ} \mathrm{C}$ for $15 \mathrm{~min}$ and $1.6 \mu \mathrm{l}$ loading buffer $(50 \%(\mathrm{v} / \mathrm{v})$ glycerol, I mM-EDTA, $0.4 \%(\mathrm{w} / \mathrm{v})$ bromophenol blue, $0.4 \%$ (w/v) xylene cyanol) added.

After electrophoresis, gels were rinsed 5 times for $5 \mathrm{~min}$ each in deionized distilled water. The RNA was transferred to nitrocellulose membrane (BA 85R597, Spectrex, Willowdale, Ontario, Canada) by bidirectional diffusion blotting (Smith \& Summers, 1980), and was fixed on to nitrocellulose by baking for $2 \mathrm{~h}$ at $60^{\circ} \mathrm{C}$ in a vacuum oven.

Hybridization of $\boldsymbol{C D N A}$ probes to $R N A$. Filters were prehybridized in a solution containing $50 \%(\mathrm{v} / \mathrm{v})$ deionized formamide, $6 \times \mathrm{SSC}(0.9 \mathrm{M}$-sodium chloride, $0.09 \mathrm{M}$-sodium citrate, $\mathrm{pH} 7.0)$ and $2.5 \%$ (w/v) Carnation Instant Skim Milk Powder heated to $42^{\circ} \mathrm{C}$ for $12-16 \mathrm{~h}$. Then $15 \mathrm{ng}$ bovine oxytocin-neurophysin cDNA (p3'OTNP1, insert DNA, approximately 180 nucleotides in length, cleaved from plasmid DNA by digestion of p3'OTNP1 with the restriction enzyme Pst I; Land et al., 1983) or $15 \mathrm{ng}$ bovine $\beta$-actin cDNA (pBAI, insert DNA, approximately 1300 nucleotides in length, cleaved from plasmid DNA by digestion of pßAl with the restriction enzyme Pst I; Degen et al., 1983) were labelled with [ $\left.{ }^{32} \mathrm{P}\right] \mathrm{dCTP}$ by a Random Primers DNA-Labelling System (BRL). The DNA was then denatured at $95^{\circ} \mathrm{C}$ for $10 \mathrm{~min}$ and added to the prehybridization solution. The filters and hybridization solution were incubated for a further $24 \mathrm{~h}$ at $42^{\circ} \mathrm{C}$. Filters were washed twice in $2 \times$ SSC with $0.1 \%$ SDS for 10 min each at room temperature, followed by two $30-\mathrm{min}$ washes in $0.1 \times \mathrm{SSC}$ with $0.1 \% \mathrm{SDS}$ at $42^{\circ} \mathrm{C}$. The membranes were dried, wrapped in plastic film and placed against a piece of X-ray film (Kodak AR film, Picker International, Bramalea, Ontario, Canada) in a 
stainless-steel cassette (Wolf Deluxe, Picker) containing two intensifying screens (Cronex Lighting Plus, Picker) at $-70^{\circ} \mathrm{C}$ for several days. Autoradiographs were developed using standard dark-room techniques.

\section{Results}

\section{Superovulation and insemination of cows}

Multiple corpora lutea $(11.8 \pm 7 \cdot 1$; mean \pm s.d.) were found in the ovaries of 19 of $22(86 \%)$ cows subjected to oestrous cycle synchronization, superovulation and artificial insemination. Sixteen cows $(73 \%)$ yielded conceptus tissue. Since conceptus tissue was prepared immediately for isolation of RNA to avoid potential degradation of the RNA, the yield of tissue from each cow could not be determined. Also, since the conceptuses become tangled during flushing it was not possible to determine the number of conceptuses in each preparation and no attempt was made to separate embryonic disc and trophoblast.

\section{Isolation of RNA}

Ribonucleic acid was isolated from each of 4 collections of Day-18 conceptus tissue (RNA preparations 1-4 in Figs 1 and 2) for a total of $11 \cdot 1 \mathrm{mg}$ RNA. Ribonucleic acid was isolated from Day-7 and two Day-8 CL. Yields of RNA from the 3 preparations ranged between 0.7 and $1.6 \mathrm{mg}$. Total CL RNA isolated from the 3 preparations was $3.4 \mathrm{mg}$.

\section{Detection of mRNA for oxytocin and $\beta$-actin}

The maximum amount of RNA $(40 \mu \mathrm{g})$ that could be loaded on the gels and still result in even electrophoretic separation of the RNA was used in all lanes. Two distinct bands representing $28 \mathrm{~S}$ and 18S RNA were evident in all lanes of conceptus and CL RNA after electrophoresis, transfer and staining with ethidium bromide and illumination with ultraviolet light.

Companion nitrocellulose membranes, prepared simultaneously in bidirectional diffusion blotting of conceptus and CL RNA, were hybridized to the ${ }^{32} \mathrm{P}$-labelled oxytocin-neurophysin (Fig. 1) and $\beta$-actin (Fig. 2) probes. Hybridization with the oxytocin-neurophysin cDNA resulted in a single $600 \mathrm{bp}$ band in lanes containing CL RNA. A hybridization signal at $600 \mathrm{bp}$ was not evident in any of the lanes containing conceptus RNA (Fig. 1), even following a 4-week re-exposure of this filter (not shown).

A single $2 \cdot 0 \mathrm{~kb}$ band was obtained in all lanes after hybridization of the $\beta$-actin probe with CL and conceptus RNA (Fig. 2). The intensity of this band was consistently greater for lanes containing conceptus RNA than lanes containing CL RNA.

\section{Discussion}

Hybridization of the oxytocin-neurophysin cDNA with CL RNA resulted in a single $0.6 \mathrm{~kb}$ band (Fig. 1). The size reported for bovine luteal oxytocin-neurophysin mRNA is $0.63 \mathrm{~kb}$ (Ivell \& Richter, 1984), indicating that the $0.6 \mathrm{~kb}$ band that was obtained for CL RNA represents oxytocinneurophysin mRNA. Although luteal oxytocin-neurophysin mRNA concentrations peak between Days 1 and 3 of the oestrous cycle, oxytocin-neurophysin mRNA concentrations at Day 8 are high relative to concentrations of the mRNA later in the cycle (Fehr et al., 1987) and so the oxytocin-neurophysin cDNA was expected to bind to this mRNA in the preparations of luteal RNA.

Hybridization of the $\beta$-actin cDNA with CL RNA resulted in a single $2.0 \mathrm{~kb}$ band (Fig. 2), which approximates the size reported for bovine lymphocyte $\beta$-actin mRNA $(2 \cdot 1 \mathrm{~kb}$; Degen et al., 1983 ), indicating that the probe hybridized with $\beta$-actin mRNA. 


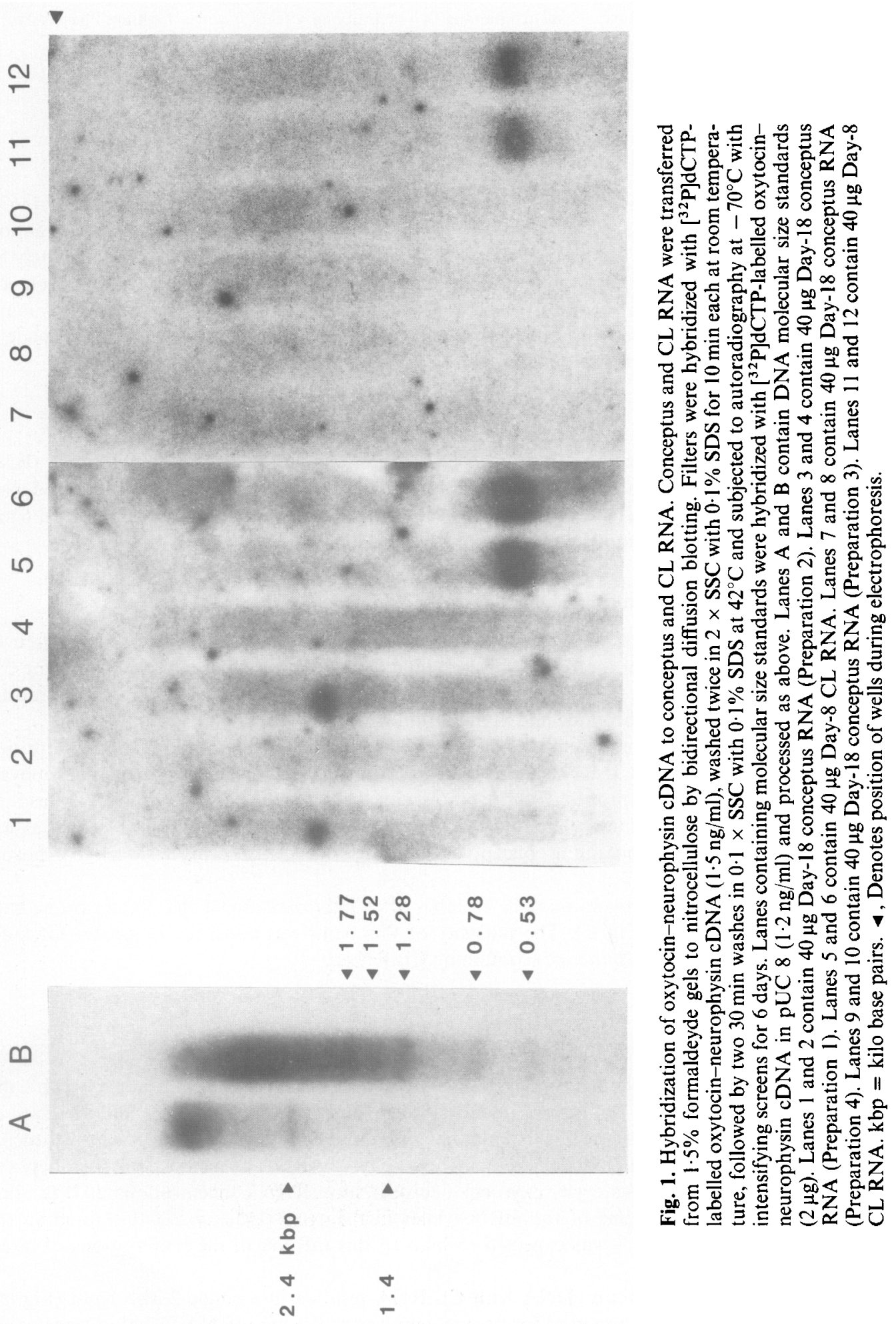




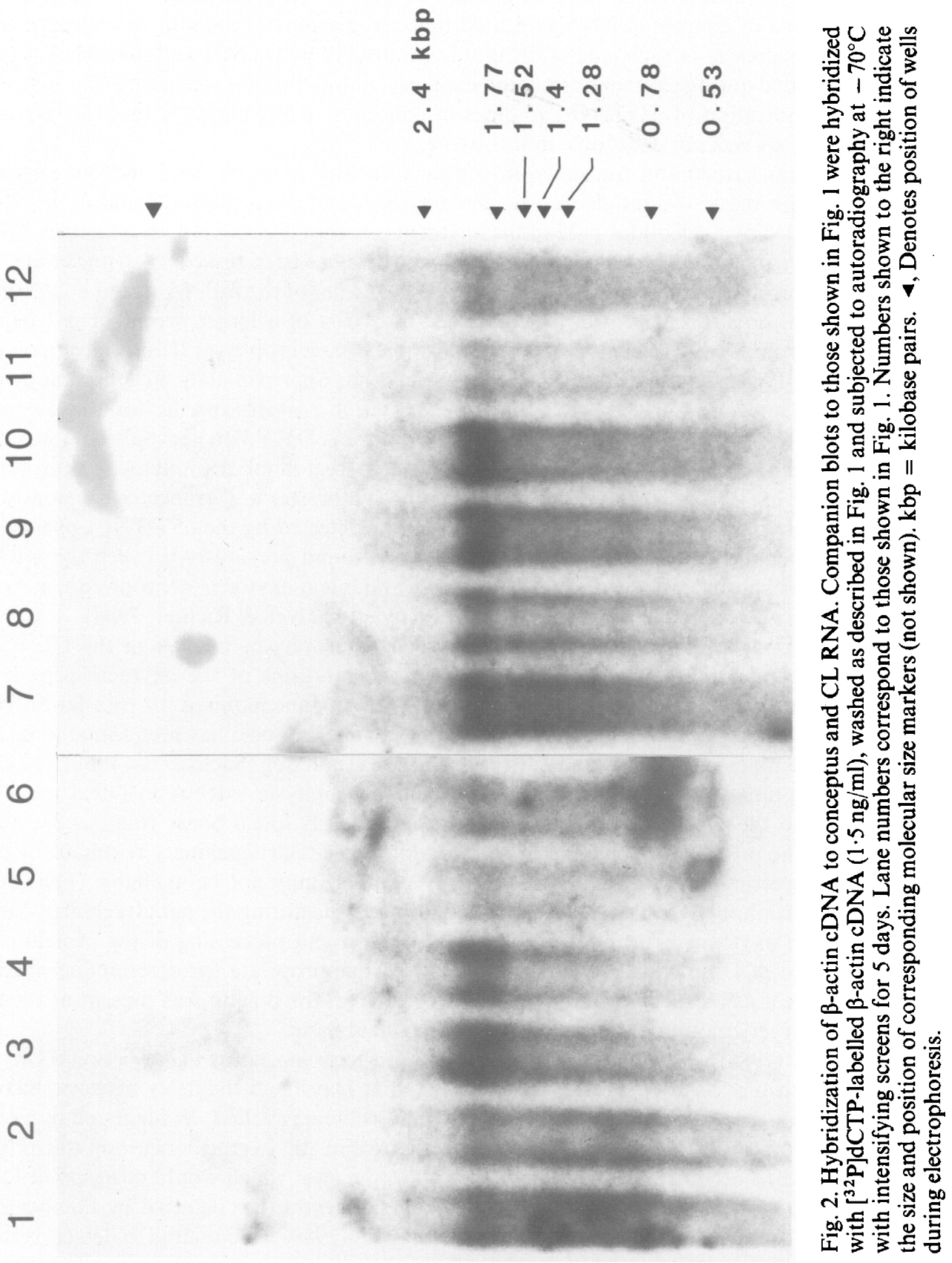


A signal corresponding to oxytocin-neurophysin mRNA was not evident after hybridization of the oxytocin-neurophysin cDNA to conceptus RNA (Fig. 1), even after prolonged exposure. However, a strong signal representative of $\beta$-actin mRNA was obtained in lanes of conceptus RNA following hybridization with the $\beta$-actin cDNA (Fig. 2). The presence of the $\beta$-actin mRNA in the preparations of conceptus RNA indicated that an appropriate amount of conceptus total cellular RNA was present in each lane of the blot hybridized to p3'OTNPI and that RNA was not excessively degraded during electrophoresis and capillary-action blotting. Therefore, the absence of a signal for hybridization of p3'OTNP1 in lanes of conceptus RNA indicates that the oxytocinneurophysin mRNA was not detectable in this tissue.

Oxytocin is transcribed and translated in conjunction with neurophysin I and the oxytocin neurophysin prohormone is later cleaved to give oxytocin and neurophysin (Land et al., 1983). Oxytocin is encoded by nucleotides 1-27 of the oxytocin-neurophysin mRNA. Nucleotides 37-315 code for neurophysin and the remainder of the cDNA, which has been cloned up to nucleotide 435, appears to code for a $3^{\prime}$ untranslated region and the poly(A) tail of the mRNA (Land et al., 1983).

Like oxytocin, bovine vasopressin is synthesized as a part of a larger precursor polypeptide which contains, from $5^{\prime}$ to $3^{\prime}$, sequences coding for vasopressin, neurophysin II and a glycopolypeptide (Land et al., 1983). The sequence for neurophysin II has approximately $80 \%$ homology with neurophysin I (Land et al., 1983), and, therefore, to select a probe specific for the oxytocinneurophysin mRNA, the portion of the oxytocin-neurophysin cDNA $3^{\prime}$ to neurophysin I was used; p3'OTNP1 corresponds primarily to the $3^{\prime}$ untranslated region of the oxytocin-neurophysin mRNA (Land et al., 1983). However, if the conceptus synthesizes a $3^{\prime}$ truncated version of the oxytocin-neurophysin mRNA, this message would not be detected by the p3'OTNP1 probe. This concept may be tenable since size heterogeneity has been found previously between the mRNAs corresponding to hypothalamic oxytocin-neurophysin and luteal oxytocin-neurophysin, although the size difference was related to differential $3^{\prime}$ polyadenylation (Ivell \& Richter, 1984).

In the cyclic cow, peak expression of the oxytocin-neurophysin mRNA in the CL occurs between Days 1 and 3 of the oestrous cycle, while concentrations of the oxytocin peptide are maximal between Days 10 and 12 (Fehr et al., 1987). Since the time required for translation, posttranslational processing and axonal transport of hypothalamic oxytocin has been found to be only a few hours in the rat (Franco-Bourland \& Fernstrom, 1981) and dog (Sachs et al., 1969), the delay between transcription and translation of the oxytocin-neurophysin mRNA in luteal tissue has been attributed to the rapid growth of the CL during the early luteal phase (Fehr et al., 1987). Thus, although the mRNA for oxytocin is synthesized, the cellular machinery required for posttranslational processing and packaging of secretory granules may not be available (Fehr et al., 1987). Since the trophoblast is also a rapidly proliferating tissue during the periattachment period, a similar delay in oxytocin-neurophysin mRNA translation and processing of the protein could occur. The choice of Day 18 may, therefore, have been inappropriate for determining maximal expression of this mRNA species. Certainly, messenger RNA for $\beta$-actin was present at the time studied, and in larger amounts than was found for the luteal tissue.

Lacroix et al. (1988) were able to detect oxytocin in sheep conceptus tissue between Days 14 and 29, and found that oxytocin concentrations peaked at Day 19. If the delay between maximal concentrations of the oxytocin-neurophysin mRNA and protein is 9 days, as suggested by Fehr $e t$ al. (1987) with respect to luteal oxytocin, peak transcription of oxytocin-neurophysin mRNA could be expected to occur at approximately Day 10 in the ewe. which would correspond to approximately Day 14 in the cow. However, the oxytocin concentrations detected by Lacroix et al. (1988) were very low (26-244 pg/blastocyst) and Flint et al. (1989) were unable to detect oxytocin in sheep blastocysts or extracts, and so, at the most, oxytocin is only present at very low concentrations. The physiological importance of small amounts of the peptide in regulating the oxytocin receptor is questionable. Moreover, detection of the peptide by radioimmunoassay cannot define whether the oxytocin detected is of conceptus origin or sequestered from the maternal endometrium. 
The results reported here indicate that oxytocin-neurophysin mRNA is not present in appreciable amounts in the bovine conceptus on Day 18. Even if low levels of oxytocin-neurophysin mRNA were present and not detectable by the method used, it seems unlikely that sufficient amounts of the oxytocin peptide would be generated to down-regulate the oxytocin receptor. Conceptus oxytocin may therefore not be important as a mechanism for abrogating luteolysis in the pregnant cow.

This work was supported by the Ontario Ministry of Agriculture and Food and by grants fom the Natural Science and Engineering Research Council of Canada and the Canadian Association of Animal Breeders. We thank S. Ruppert and D. R. Morris for generous provision of cDNAs for oxytocin-neurophysin I and $\beta$-actin, respectively; $\mathrm{K}$. Copeland for helpful advice; and $\mathbf{M}$. Goodwin, C. Watson and C. Haworth for excellent technical assistance.

\section{References}

Degen, J.L., Neubauer, M.G., Degen, S.J.F., Seyfried, C.E. \& Morris, D.R. (1983) Regulation of protein synthesis in mitogen-activated bovine lymphocytes. J. biol. Chem. 258, 12153-12162.

Fehr, S., Ivell, R., Koll, R., Schams, D., Fields, M. \& Richter, D. (1987) Expression of the oxytocin gene in the large cells of the bovine corpus luteum. FEBS Lett. 210, 45-50.

Flint, A.P.F. \& Sheldrick, E.L. (1985) Continuous infusion of oxytocin prevents induction of uterine oxytocin receptor and blocks luteal regression in cyclic ewes. $J$. Reprod. Fert. 75, 623-631.

Flint, A.P.F., Sheldrick, E.L., Jones, D.S.C.\& Auletta, F.J. (1989) Adaptations to pregnancy in the interactions between luteal oxytocin and the uterus in ruminants. J. Reprod. Fert., Suppl. 37, 195-204.

Franco-Bourland, R.E. \& Fernstrom, J.D. (1981) In vivo biosynthesis of L-[35S]cys-arginine vasopressin, -oxytocin and -somatostatin: rapid estimation using reversed phase high pressure liquid chromatography. Endocrinology 109, 1097-1106.

Gilbert, C.L., Lamming, G.E., Parkinson, T.J., Flint, A.P.F. \& Wathes, D.C. (1989) Oxytocin infusion from Day 10 after oestrus extends the luteal phase in non-pregnant cattle. J. Reprod. Fert. 86, 203-210.

Ivell, R. \& Richter, D. (1984) The gene for the hypothalamic peptide hormone oxytocin is highly expressed in the bovine corpus luteum: biosynthesis, structure and sequence analysis. $E M B O J / 5,2351-2354$.

Kindahl, H., Edqvist, L.-E., Granstrom, E. \& Bane, A. (1976) The release of prostaglandin F2 $\alpha$ as reflected by 15-keto-13,14-dehydro prostaglandin F2a in the peripheral circulation during normal luteolysis in heifers. Prostaglandins 11, 871-878.

Lacroix, M.C., Charpigny, G. \& Reinaud, P. (1988) Is oxytocin of conceptus origin involved in inhibition of luteal regression in early pregnancy in ewes? $J$. Endocr. 118, R17-R20.

Lafrance, M. \& Goff, A.K. (1985) Effect of pregnancy on oxytocin-induced release of prostaglandin $F 2_{a}$ in heifers. Biol. Reprod. 33, 1113-1119.

Land, H., Grez, M., Ruppert, S., Schmale, H., Rehbein, M., Richter, D. \& Schutz, G. (1983) Deduced amino acid sequence from the bovine oxytocin-neurophysin I precursor cDNA. Nature, Lond. 302, 342-344.

Maniatis, T., Fritsch, E.F. \& Sambrook, J. (1982) Molecular Cloning, a Laboratory Manual. Cold Spring Harbour Laboratory, Cold Spring Harbour.
Meyer, H.H.D., Mittermeier, Th. \& Schams, D. (1988) Dynamics of oxytocin, estrogen and progestin receptors in the bovine endometrium during the estrous cycle. Acta endocr., Copenh. 118, 96-104.

Northey, D.C. \& French, L.R. (1980) Effect of embryo removal and intrauterine infusion of embryonic homogenates on the lifespan of the bovine corpus luteum. J. Anim. Sci. 50, 298-302.

Sachs, H., Fawcett, P., Takabatake, Y. \& Portanova, R. (1969) Biosynthesis and release of vasopressin and neurophysin. Recent Prog. Horm. Res. 25, 447-491.

Schams, D., Shallenberger, E., Meyer, H.H.D., Bullermann, B., Breitinger, H.-J., Enzenhofer, G., Koll, R., Kruip, T.A.M., Walter, D.L. \& Karg, H. (1985) Ovarian oxytocin during the estrous cycle in cattle. In Oxytocin, Clinical and Laboratory Studies, pp. 317-334. Eds J. A. Amico \& A. G. Robinson. Elsevier, Amsterdam.

Sheldrick, E.L. \& Flint, A.P.F. (1985) Endocrine control of uterine oxytocin receptors in the ewe. J. Endocr. 106, 249-258.

Sheldrick, E.L. \& Flint, A.P.F. (1987) Effect of continuous oxytocin infusion on prostaglandin-F2 $\alpha$ secretion in the cyclic ewe. J. Endocr., Suppl. 115, Abstr. 36.

Sheldrick, E.L., Mitchell, M.D. \& Flint, A.P.F. (1980) Delayed luteal regression in ewes immunized against oxytocin. J. Reprod. Fert. 59, 37-42.

Smith, G.E. \& Summers, M.D. (1980) The bidirectional transfer of DNA and RNA to nitrocellulose or diazobenzyloxymethyl-paper. Analyt. Biochem. 109, $123-129$.

Solofi, M.S. \& Fields, M.J. (1989) Changes in uterine oxytocin receptor concentrations throughout the estrous cycle of the cow. Biol. Reprod. 40, 283-287.

Thatcher, W.W., Wolfensen, D., Curl, J.S., Rico, L.E., Knickerbocker, J.J., Bazer, F.W. \& Drost, M. (1984) Prostaglandin dynamics associated with development of the bovine conceptus. Anim. Reprod. Sci. 7, 149-176.

Walton, J.S. \& Stubbings, R.B. (1986) Factors affecting the yield of viable embryos by superovulated HolsteinFriesian cows. Theriogenology 26, 167-177. 